\title{
STUDY ON THERMODYNAMICS AND ADSORPTION KINETICS OF PURIFIED ENDOGLUCANASE (CMCASE) FROM PENICILLIUM NOTATUM NCIM NO-923 PRODUCED UNDER MIXED SOLID-STATE FERMENTATION OF WASTE CABBAGE AND BAGASSE
}

\author{
Arpan Das ${ }^{1}$, Uma Ghosh ${ }^{2}$, Pradeep Kumar Das Mohapatra ${ }^{1}$, Bikas Ranjan Pati ${ }^{1}$, Keshab Chandra Mondal ${ }^{\text {* }}$ \\ ${ }^{1}$ Department of Microbiology, Vidyasagar University, Midnapore - 721102, West Bengal, India; ${ }^{2}$ Food Technology and \\ Biochemical Engineering Department, Jadavpur University Kolkata-700032, West Bengal, India.
}

Submitted: February 22, 2011; Returned to authors for corrections: December 09, 2011; Approved: June 07, 2012.

\begin{abstract}
In the current study, one thermostable endoglucanase was purified from Penicillium notatum NCIM NO-923 through mixed solid state fermentation of waste cabbage and bagasse. The molecular weight of the purified enzyme was $55 \mathrm{kDa}$ as determined by SDS polyacrylamide gel electrophoresis (SDS-PAGE). The enzyme had low activation energy $\left(\mathrm{E}_{\mathrm{a}}\right)$ of $36.39 \mathrm{KJ} \mathrm{mol}^{-1}$ for carboxymethyl cellulose hydrolysis and the enthalpy and entropy for irreversible inactivation was $87 \mathrm{~kJ} \mathrm{~mol}^{-1}$ and $59.3 \mathrm{~J} \mathrm{~mol}^{-1} \mathrm{~K}^{-1}$ respectively. The enzyme was quite thermostable with a $\mathrm{T}_{\mathrm{m}}$ value of $62.2^{\circ} \mathrm{C}$. The $\mathrm{pK}_{\mathrm{a} 1}$ and $\mathrm{pK}_{\mathrm{a} 2}$ of ionizable groups of the active sites were 2.5 and 5.3 respectively. Apparent $\mathrm{K}_{\mathrm{m}}, \mathrm{V}_{\max }$ and $\mathrm{K}_{\text {cat }}$ of the enzyme were found to be $5.2 \mathrm{mg} \mathrm{mL}^{-1}, 80$ $\mathrm{U} / \mathrm{gds}$ and $322.4 \mathrm{sec}^{-1}$ respectively. The enzyme showed about 1.4 fold increased activity in presence of $10 \mathrm{mM} \mathrm{MgSO}_{4}$. Adsorption of endoglucanase on Avicel at wide $\mathrm{pH}$ range was studied at different temperatures. Langmuir type adsorption isotherm at $10^{\circ} \mathrm{C}$ showed maximum adsorption strength of enzyme at $\mathrm{pH} 3.0$, which was in a range of optimum $\mathrm{pH}$ of the enzyme.
\end{abstract}

Key words: Endoglucanase, Langmuir adsorption isotherm, Penicillium notatum, Solid state fermentation

\section{INTRODUCTION}

Cellulose, a homopolymer of anhydro-D-glucose linked by $\beta-1,4$ bonds, is the most abundant biopolymer on the earth. Enzymatic degradation of cellulose to glucose requires the cooperative action of endo-1,4- $\beta$-glucanase (EC 3.2.1.4), exo1,4- $\beta$ glucanase (EC 3.2.1.91), and $\beta$-glucosidase (EC 3.2.1.21) (1).
Biotechnology of Cellulases and hemicellulases began in early 1980s, first in animal feed, followed by food, brewing and alcohol industries. Subsequently, these were used in textile, laundry and paper industries (2). Although ability to synthesize cellulases and hemicellulases is widely spread among microorganisms, only some are able to synthesize these enzymes in industrially important amount which include fungal

*Corresponding Author. Mailing address: Department of Microbiology, Vidyasagar University, Midnapore - 721102 West Bengal, India.; Tel.: (91) 03222276554/555 (ext. 477) Fax: (91) 03222-275329.; E-mail: mondalkc@gmail.com 
genera of Trichoderma, Sporotrichum, Fusarium, Humicola, Talaromyces, Penicillium etc (3). Unlike Trichoderma, those of genus Penicillium synthesize more balanced cellulolytic complexes, which efficiently degrade cellulose and cellulosecontaining residues. In addition, enzymes produced by Penicillium fungi were found to be more stable (4). Due to energy and food storage, which is likely to become more predominant in near future, reuse of waste cellulose has become more important. Various agricultural wastes such as wheat straw, saw dust, bagasse, corncob willow, oat bran, wheat bran and rice straw $(5,6)$ have been used successfully in solid state fermentation (SSF) for cellulase production. Thus the present study was undertaken to assess suitability of waste cabbage and bagasse as substrates of SSF for production and purification of cellulase enzyme, and this is the first report on utilization of cabbage for purification of cellulases from Penicillium notatum NCIM NO-923.

Researchers generally use sugar yield or determination of enzyme activity in supernatant of resultant hydrolysate to express efficiency of reused enzyme. It has been difficult to evaluate the reuse and or recycle of cellulases, primarily because our insufficient knowledge on the characteristics of cellulase adsorption onto cellulosic substrates. The aim of the present work was to investigate the physio-chemical characteristics of purified endoglucanase and to study the changes in its adsorption isotherm on microcrystalline cellulose (Avicel PH101) at varying environmental conditions $(\mathrm{pH}$ and temperature).

\section{MATERIALS AND METHODS}

\section{Microorganism}

Penicillium notatum NCIM NO-923 was obtained from the department of Food Technology and Biochemical Engineering, Jadavpur University, India. The sporulated culture was maintained at $4{ }^{\circ} \mathrm{C}$ on Potato Dextrose Agar slant, with regular subculturing after every 3-4 week. The spores were harvested by swirling in sterile distilled water with $0.1 \%$ Tween 80 and diluted with the same up to $10^{7}$ spores $/ \mathrm{mL}$.

\section{Solid state fermentation}

Solid state fermentation was carried out in $250 \mathrm{~mL}$ Erlenmeyer flask. $5 \mathrm{~g}$ of sugar cane bagasse and untreated sun dried cabbage (in a proportion of $2: 3 \mathrm{w} / \mathrm{w}$ ) was mixed with water with a substrate to moisture ratio of 4:3. Following sterilization at $121^{\circ} \mathrm{C}$ for $20 \mathrm{~min}$, all flasks were inoculated with $10 \%(\mathrm{w} / \mathrm{v})$ spore suspensions and were incubated at $30^{\circ} \mathrm{C}$ for $48 \mathrm{~h}$.

\section{Enzyme assay}

Endoglucanase or CMCase (E.C. 3.2.1.4) activity was determined by incubating $0.5 \mathrm{~mL}$ of diluted enzyme with 0.5 $\mathrm{mL}$ of $1 \%$ carboxymethyl cellulose (high viscosity $\mathrm{CMC}$, SIGMA) in $0.05 \mathrm{M}$ sodium citrate buffer $(\mathrm{pH} 4.8)$ at $50^{\circ} \mathrm{C}$ for $30 \mathrm{~min}$. After incubation the reaction was terminated by adding $3 \mathrm{~mL}$ of 3,5-dinitrosalicylic acid (DNS) reagent to $1 \mathrm{~mL}$ of the reaction mixture. Reducing sugars were estimated colorimetrically with 3, 5- dinitrosalicylic acid (7) using glucose as standard.

\section{Preparation of the crude enzyme}

For harvesting the crude CMCase, $50 \mathrm{~mL}$ of distilled water was added in the fermented pith and shaken vigorously on orbital shaker at $120 \mathrm{rpm}$ for $3 \mathrm{~h}$. The crude enzyme was filtered, centrifuged at $10,000 \times \mathrm{g}$ for $10 \mathrm{~min}$ and then concentrated by rotary evaporator (Eyela, Japan).

\section{Ammonium sulfate precipitation}

All purification steps were performed at $4{ }^{\circ} \mathrm{C}$ unless otherwise stated. Crude extract was subjected to $80 \%$ ammonium sulfate saturation and was kept overnight at $4{ }^{\circ} \mathrm{C}$ to precipitate the protein. Resulting precipitate was collected by centrifugation at $10,000 \times \mathrm{g}$ for $10 \mathrm{~min}$, dissolved in $0.05 \mathrm{M}$ acetate buffer $(\mathrm{pH} 4.8)$ and dialyzed for $24 \mathrm{~h}$ against the same buffer with four changes of equal intervals. Total proteins and 
CMCase activity was determined before and after dialyzing the sample.

\section{DEAE- ion exchange chromatography}

For this, dialyzed enzyme preparation was applied to a DEAE cellulose column $(50 \times 1 \mathrm{~cm})$ pre equilibrated with elution buffer (50mM sodium acetate buffer; $\mathrm{pH} 4.8)$. Elution was achieved with a linear gradient of $0.1-1 \mathrm{M} \mathrm{NaCl}$ at a flow rate of $0.3 \mathrm{~mL} / \mathrm{min}$. The purified fractions were collected using a fraction collector. The absorbance profile of each $5 \mathrm{~mL}$ fraction was studied at $280 \mathrm{~nm}$ using spectrophotometer for the presence of protein and analyzed for CMCase activity. The active fractions were pooled, re-dialyzed and concentrated upto homogeneity level.

\section{Sephadex G100 column chromatography}

The enzyme from DEAE column was further purified on Sephadex G-100 (Sigma, St. Louis, MO) column $(80 \times 2 \mathrm{~cm})$. The enzyme was eluted with $0.05 \mathrm{M}$ acetate buffer $(\mathrm{pH} 4.8)$ at a flow rate of $1 \mathrm{~mL} / \mathrm{min}$. Eluted protein fractions were collected through fraction collector and the active part was pooled and concentrated.

\section{Determination of the molecular weight by polyacrylamide gel electrophoresis}

Molecular mass and the purity of the purified CMCase was determined by sodium dodecyl-sulphate polyacrylamide gel electrophoresis (10\% SDS-PAGE), using a BioRad gel electrophoresis apparatus. After electrophoresis, gels were stained by Coomassie blue R-250. Molecular mass was determined against standard markers proteins (Sigma).

\section{Zymogram analysis}

For zymogram analysis, purified endoglucanase was subjected to $10 \%$ polyacrylamide gel electrophoresis with $0.1 \%$ carboxymethyl cellulose. After electrophoresis, gel was incubated in $0.05 \mathrm{M}$ acetate buffer $(\mathrm{pH}-4.0)$ for $1 \mathrm{~h}$. The clear hydrolysis zone that corresponded to enzyme activity was visualized using $0.5 \%(\mathrm{w} / \mathrm{v})$ Congo red (8).

\section{Determination of optimum pH, temperature and Thermostability}

The optimum $\mathrm{pH}$ was determined by measuring the activity at $50^{\circ} \mathrm{C}$ using the following buffers: $50 \mathrm{mM}$ citratephosphate $(\mathrm{pH} 2.0-4.0), 50 \mathrm{mM}$ sodium acetate $(\mathrm{pH} 4.0-6.0)$ and $50 \mathrm{mM}$ phosphate $(\mathrm{pH}$ 6.0-7.0). Temperature optimum was determined by assaying the enzyme activity at several temperatures $\left(30\right.$ to $\left.70^{\circ} \mathrm{C}\right)$ at $\mathrm{pH} 4.0$.

Thermostability of enzymes was determined by pre incubation of the enzyme solutions at varying temperature range $30-70^{\circ} \mathrm{C}$ (in $0.05 \mathrm{M}$ sodium acetate buffer, $\mathrm{pH} 4.0$ ) in the absence of substrates. Aliquots were removed at different times between 0 and $2 \mathrm{~h}$ and immediately cooled on ice. The treated enzyme solutions were then assayed for residual enzymatic activities using standard assay conditions.

\section{Effect of metallic ions on the enzyme activity}

The enzyme activity was measured in the presence of some metal ions at 5 and $10 \mathrm{mM}$ concentrations, and the residual activity was determined. The stock ionic solutions used in this study were prepared in distilled water at the concentration of $1 \mathrm{M}: \mathrm{BaCl}_{2}, \mathrm{CoSO}_{4}, \mathrm{CuSO}_{4}, \mathrm{CaCl}_{2}, \mathrm{ZnCl}_{2}$, and $\mathrm{FeSO}_{4}$.

\section{Adsorption studies}

During adsorption study of the purified enzyme, Avicel pH 101 was used as the adsorbing substrate. $20 \mathrm{mg}$ Avicel was mixed with $2 \mathrm{~mL}$ buffer solution of various $\mathrm{pH}$ (4.0-8.0) values with a purified enduglucanase load of $0-1 \mathrm{mg} / \mathrm{mL}$. After incubation for $45 \mathrm{~min}$ at $10^{\circ} \mathrm{C}$ with shaking, reaction mixture was centrifuged for $5 \mathrm{~min}$ at $5,000 \times \mathrm{g}$. The amount of protein in the supernatant was determined by the Lowry et.al method (9) using bovine serum albumin as standard.

\section{RESULTS AND DISCUSSION}

\section{Enzyme purification}

The purification profile of endoglucanase from Sephadex G100 column showed sharp peak of endoglucanase activity 
obtained from fractions 35-40 using an $\mathrm{NaCl}$ concentration of 0.2-0.3M (Fig. 1). The purified endoglucanase had a specific activity of $50.2 \mathrm{U} / \mathrm{mg}$ with a $28.99 \%$ recovery. The results are summarized in Table 1.
The active fraction showed a single band on SDS-PAGE analysis, having a mass of $\sim 55 \mathrm{kDa}$ (Fig. 2). The zymogram analysis of the corresponding band exhibited CMCase activity when observed after staining with Congo red.

Table 1. Profile of step wise endoglucanase (CMCase) purification from Penicillium notatum NCIM NO-923 under mixed solid state fermentation of waste cabbage and bagasse.

\begin{tabular}{lccccc}
\hline \multicolumn{1}{c}{ Treatment } & $\begin{array}{c}\text { Total enzyme } \\
(\mathbf{U})\end{array}$ & $\begin{array}{c}\text { Total protein } \\
(\mathbf{m g})\end{array}$ & $\begin{array}{c}\text { Specific activity } \\
(\mathbf{U} / \mathbf{m g})\end{array}$ & $\begin{array}{c}\text { Purification } \\
\text { factor }\end{array}$ & \% Recovery \\
\hline $\begin{array}{l}\text { Crude enzyme } \\
\text { (NH4) } \text { SO }_{2} \text { precipitation }\end{array}$ & 3325 & 1269 & 2.62 & 1 & 100 \\
$\begin{array}{l}\text { DEAE ion exchange } \\
\text { chromatography }\end{array}$ & 2581 & 637 & 4.05 & 1.54 & 77.62 \\
$\begin{array}{l}\text { Sephadex G100 column } \\
\text { chromatography }\end{array}$ & 1513 & 69.0 & 21.92 & 8.36 & 45.5 \\
\hline
\end{tabular}

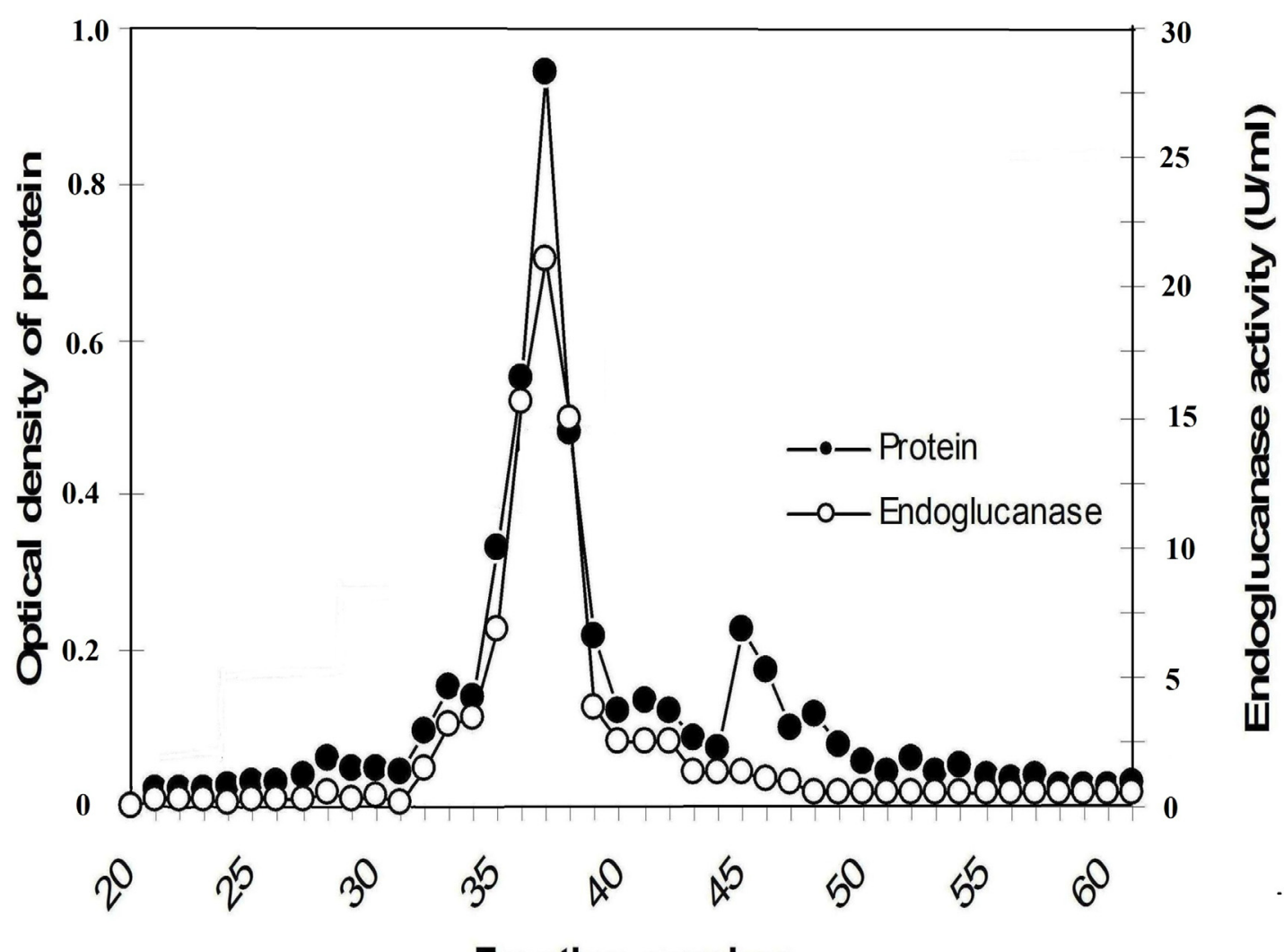

\section{Fraction number}

Figure 1. Sephadex G150 column chromatography of endoglucanase from Penicillium notatum NCIM NO-923. Active fraction was collected from fraction no.35-40. 


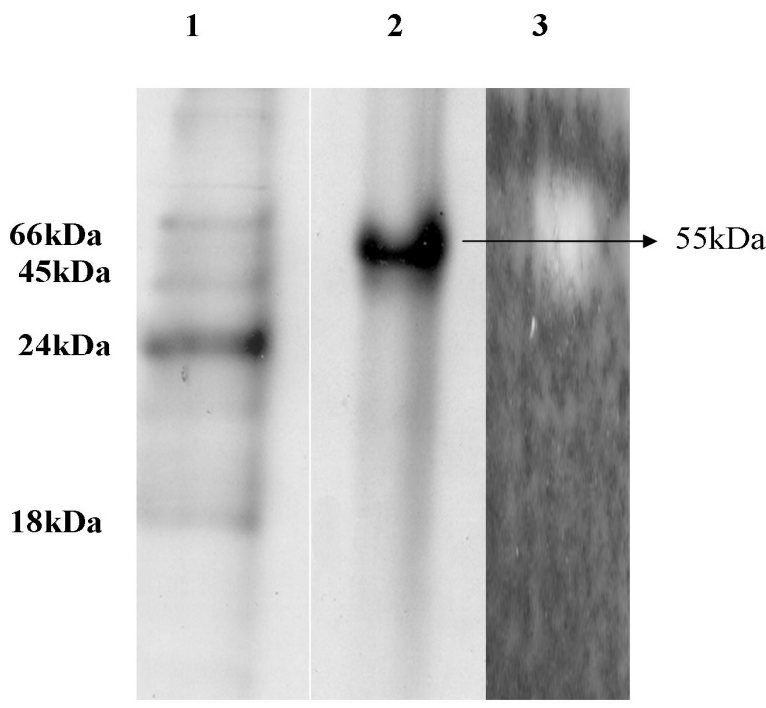

Figure 2. Polyacrylamide gel electrophoresis of endoglucanase from Penicillium notatum NCIM NO-923. Lane 1 Molecular marker proteins, Lane 2 purified endoglucanase, Lane 3 zymogram band of purified endoglucanase after staining with $0.1 \%$ congo red.

\section{Effect of pH on endoglucanase activity}

The effect of $\mathrm{pH}$ on enzymatic activities was tested at $\mathrm{pH}$ values from 2.0 to 7.0 using different buffers under standard assay conditions as described before. CMCase had $\mathrm{pH}$ optima in a range of 3-5. A Dixon plot (10) (Fig. 3) was applied to determine the $\mathrm{pK}_{\mathrm{a}}$ values of the active site residues that control $\mathrm{V}_{\max }$ of the enzyme. Generally two carboxyls are involved in the catalytic mechanism of most hydrolases; one donates protons to the substrate while the other stabilizes it (11). The $\mathrm{pK}_{\mathrm{a} 1}$ for proton donating ionizable group and proton receiving residues were 2.5 and 5.3 respectively. Comparison of the $\mathrm{pK}_{\mathrm{a}}$ values of the ionizable groups of amino acids revealed that $\alpha$ carboxyl might be acting as proton donor during catalysis. On the other hand, the $\mathrm{pK}_{\mathrm{a} 2}$ of ionizable groups involved in catalysis as proton receiver was comparable with the imidazole group. The active site residues for A. niger CMCases have been determined containing carboxyl as ionizable group with $\mathrm{pK}_{\mathrm{a}}$ values of 3.5 and 5.5, respectively (12). Endoglucanases from Schizophyllum commune also involve with the amino acid residues with $\mathrm{pKa}$ values of 3.7 and 6.1 for $\mathrm{CMC}$ catalysis (13). The presence of histidine residues in the active site domain of $A$. niger and A. awamori glucoamylase has also previously been reported (14).

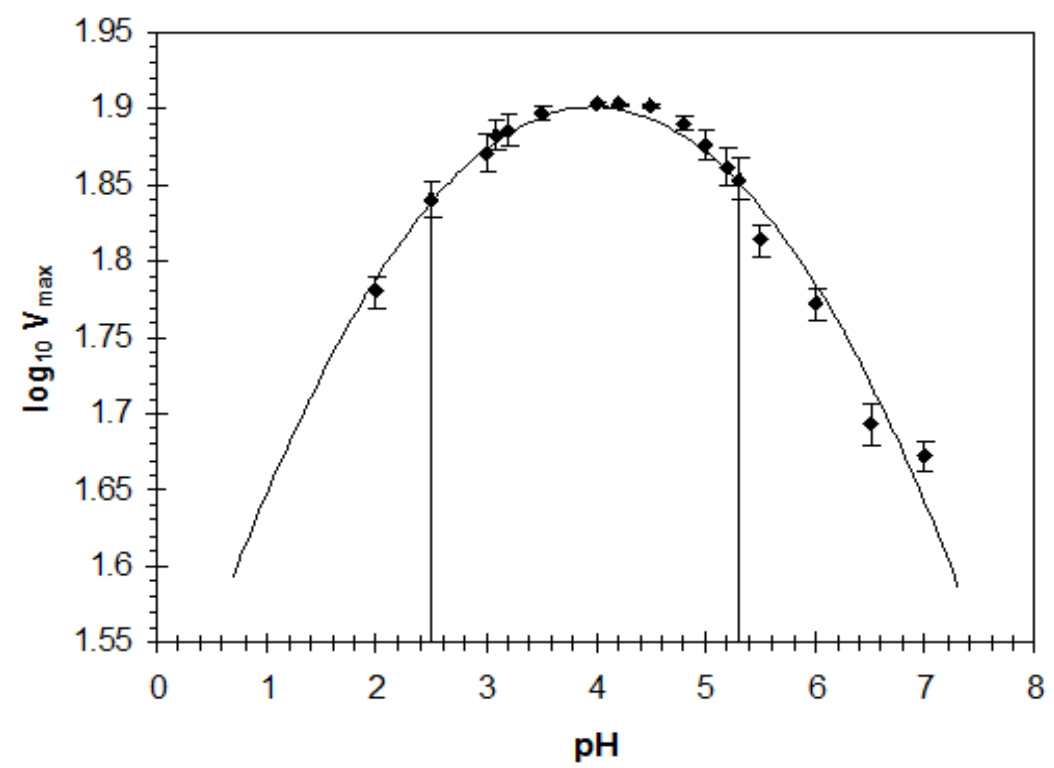

Figure 3. Dixon plot for the effect of $\mathrm{pH}$ on endoglucanase activity and determination of $\mathrm{pK}_{\mathrm{a}}$ of ionizeable groups of active side residue. Data presented are average value $+/-\operatorname{SD}$ of $n=3$ experiments. 


\section{Effect of temperature on endoglucanase activity}

To determine the optimal temperature, the reaction mixtures were incubated at temperature ranging from 30 to $70^{\circ} \mathrm{C}$ at $\mathrm{pH}$ 4.0. Then the enzymatic activities were assayed using standard conditions. Temperature optimum for CMCase activity was found to be $50^{\circ} \mathrm{C}$. An Arrhenius plot (15) for activation energy $\left(E_{a}\right)$ was calculated from the curve (Fig. 4) and found to be $36.39 \mathrm{~kJ} \mathrm{~mol}^{-1}$. During thermostability study, the denaturation midpoint temperature $\left(\mathrm{T}_{\mathrm{m}}\right)$ was determined and found to be $62.2^{\circ} \mathrm{C}$ (Table 2). The thermodynamic parameters were calculated by rearranging the Eyring absolute rate equation (16) to study the overall thermodynamic parameters in the range $30-70^{\circ} \mathrm{C}$.
Table 2. Kinetics and thermodynamics property of purified endoglucanase (CMCase) from Penicillium notatum NCIM NO-923.

\begin{tabular}{|c|c|}
\hline Parameters & Endoglucanase \\
\hline $\operatorname{Tm}\left({ }^{\circ} \mathrm{C}\right)$ & 62.2 \\
\hline $\mathrm{K}_{\mathrm{m}}\left(\mathrm{mg} \mathrm{mL}^{-1}\right)$ & 5.2 \\
\hline $\mathrm{V}_{\max }(\mathrm{U} / \mathrm{gds})$ & 80 \\
\hline $\mathrm{K}_{\text {cat }}\left(\sec ^{-1}\right)$ & 322.4 \\
\hline $\mathrm{K}_{\mathrm{cat}} / \mathrm{K}_{\mathrm{m}}$ & 62 \\
\hline $\mathrm{pK}_{\mathrm{a} 1}(\mathrm{acid} \operatorname{limb})^{\mathrm{a}}$ & 2.5 \\
\hline $\mathrm{pK}_{\mathrm{a} 2}\left(\right.$ basic limb $^{\mathrm{b}}$ & 5.3 \\
\hline $\mathrm{E}_{\mathrm{a}}\left(\mathrm{KJ} \mathrm{mol}^{-1}\right)^{\mathrm{c}}$ & 36.39 \\
\hline$\Delta \mathrm{H} *(\mathrm{~kJ} \mathrm{~mol}-1)$ & 87 \\
\hline$\Delta \mathrm{S} *(\mathrm{~J} \mathrm{~mol}-1 \mathrm{~K}-1)$ & 59.3 \\
\hline$\Delta \mathrm{G}_{\mathrm{E}-\mathrm{T}}^{\#}\left(\mathrm{KJ} \mathrm{mol}^{-1}\right)^{\mathrm{d}}$ & -21.5 \\
\hline$\Delta \mathrm{G}_{\mathrm{E}-\mathrm{S}}^{\#}\left(\mathrm{KJ} \mathrm{mol}^{-1}\right)^{\mathrm{e}}$ & 3.8 \\
\hline $\begin{array}{l}\text { Nucleophelic carboxyl grou } \\
\text { Proton donating carboxyl gr } \\
\text { Activation energy } \\
\text { Free energy of transition sta }\end{array}$ & \\
\hline
\end{tabular}

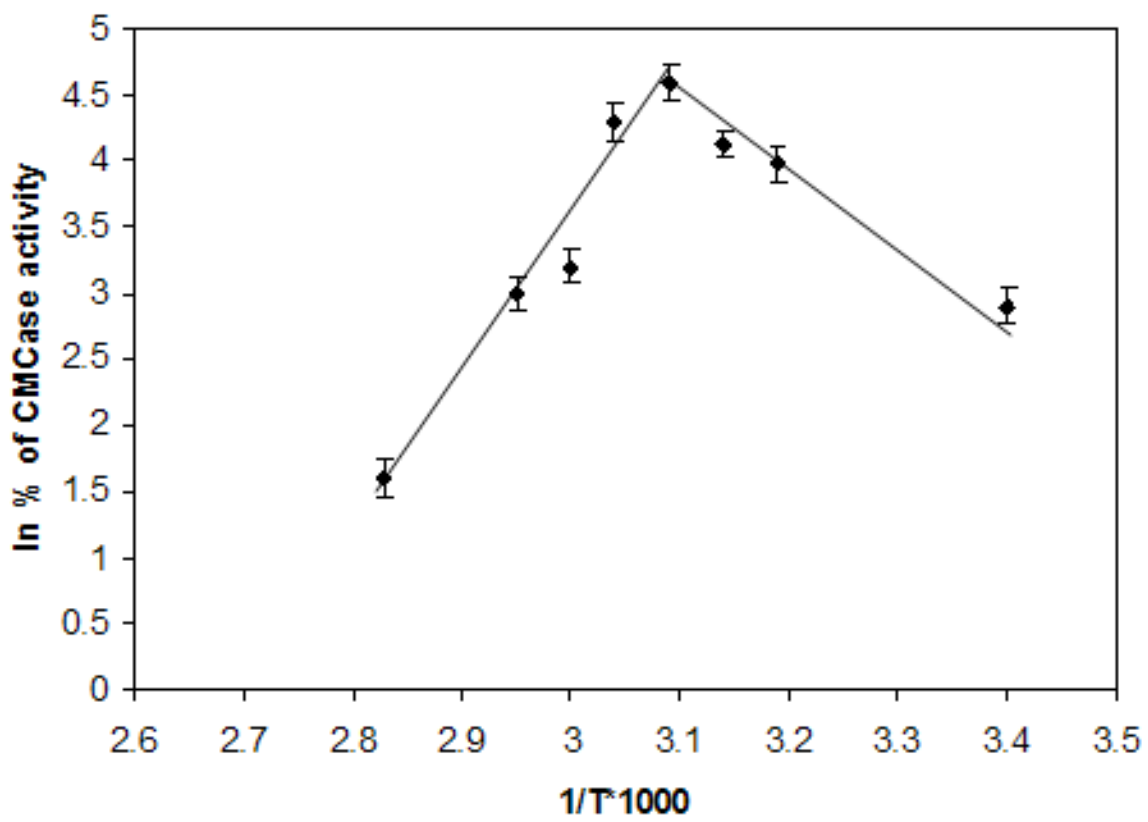

Figure 4. Arrhenius plot for effect of temperature and determination of activation energy for carboxy methyl cellulose hydrolysis. Data presented are average value $+/-\mathrm{SD}$ of $\mathrm{n}=3$ experiments.

\section{Enzyme kinetics and thermodynamics study}

Classical Michaelis-Menten kinetics were observed with $\mathrm{CMC}$ as the substrate for CMCase, and the apparent $\mathrm{K}_{\mathrm{m}}$ and $\mathrm{V}_{\max }$ values calculated from a Lineweaver-Burk plot were 5.2 $\mathrm{mg} \mathrm{mL} \mathrm{m}^{-1}$ and $80 \mathrm{U} / \mathrm{gds}$. While Turn over number $\left(\mathrm{K}_{\mathrm{cat}}\right)$ and catalytic efficiency $\left(\mathrm{K}_{\mathrm{cat}} / \mathrm{K}_{\mathrm{m}}\right)$ were determined to be $322.4 \mathrm{~s}^{-1}$ and 62 respectively. The data on free energy for substrate binding $\left(\Delta \mathrm{G}^{*}{ }_{\mathrm{E}-\mathrm{S}}\right)$ and formation of activated complex $\left(\Delta \mathrm{G}^{*}{ }_{\mathrm{E}-\mathrm{T}}\right)$ showed that the affinity to carboxymethyl cellulose and the formation of transition complex was high (Table 2) for 
endoglucanase from Penicillium notatum NCIM NO-923.

In thermal inactivation, native enzyme becomes unfolded which could be reversibly refolded upon cooling or is permanently inactivated after prolonged exposure to heat. The disintegration of the enzyme structure is accompanied by an increase in randomness or entropy of activation (15). The enzyme had a lower enthalpy of deactivation $(\Delta \mathrm{H} * ; 87 \mathrm{~kJ}$ mol $-1)$ and entropy of deactivation $(\Delta \mathrm{S} * ; 59.3 \mathrm{~J} \mathrm{~mol}-1 \mathrm{~K}-1)$ in the temperature range $30-70^{\circ} \mathrm{C}$. The result indicates that stabilization of enzymes is mostly accompanied by a decrease in $\Delta \mathrm{S} *$ and $\Delta \mathrm{H} *(12,17)$.

\section{Effects of metal ions on endoglucanase activity}

Table 3 shows the results of activity in presence of various divalent ions added at 5 or $10 \mathrm{mM}$. Magnesium at $10 \mathrm{mM}$ greatly activates the enzyme ending up with $138.8 \%$ of relative activity, followed by $\mathrm{Ca}^{2+}, \mathrm{Zn}^{2+}$ and $\mathrm{Ba}^{2+}$ ions. Inversely, $\mathrm{Fe}^{2+}$ decreased the activity to $66.8 \%$. Cobalt has no effect on enzyme activity.

Table 3. Effect of metal ions on endoglucanase activity from Penicillium notatum NCIM NO-923.

\begin{tabular}{ccc}
\hline Cataion & \multicolumn{2}{c}{ Residual endoglucanase activity } \\
\cline { 2 - 3 } & $\mathbf{5 m M}$ & $\mathbf{1 0 m M}$ \\
\hline $\mathrm{Ca}^{2+}$ & 115.4 & 128.4 \\
$\mathrm{Zn}^{2+}$ & 112.4 & 121.8 \\
$\mathrm{Cu}^{2+}$ & 72.8 & 85.9 \\
$\mathrm{Co}^{2+}$ & 95.8 & 98.5 \\
$\mathrm{Ba}^{2+}$ & 103.9 & 112.8 \\
$\mathrm{Mg}^{2+}$ & 127.4 & 138.8 \\
$\mathrm{Fe}^{2+}$ & 85.4 & 66.8 \\
Control & 100 & 100 \\
\hline
\end{tabular}

\section{Adsorption study}

The adsorption kinetic results of endoglucanase from Penicillium notatum NCIM NO-923 showed that the \% of adsorption of endoglucanase on Avicel was maximum at $10^{\circ} \mathrm{C}$ while beyond $30^{\circ} \mathrm{C}$ it decreased (data not shown). With the increase in temperature, endoglucanase bound on the surface of Avicel became more accessible to the substrate and as a result due to hydrolysis of cellulose at these higher temperatures the adsorption behavior of endoglucanase was affected.

Therefore this incubation time was chosen for the isotherm experiments. The adsorption parameter values were determined using the Langmuir adsorption (18) isotherm equation in order to obtain a quantitative analysis of the effect of $\mathrm{pH}$ on endoglucanase adsorption. From the Langmuir adsorption isotherm, the adsorption of cellulase can be described as follows:

$$
(\mathrm{A})=\left\{\left(\mathrm{A}_{\max }\right) \mathrm{K}_{\mathrm{ad}}(\mathrm{E})\right\} / 1+\mathrm{K}_{\mathrm{ad}}(\mathrm{E})
$$

where $A_{\max }$ and $K_{\text {ad }}$ are the maximum amount of enzyme adsorbed per unit weight of cellulose and the adsorption equilibrium constant, respectively. (E) is the concentration of enzyme in liquid phase at the adsorption equilibrium. Fig. 5 represents the adsorption isotherm of purified endoglucanase at varying $\mathrm{pH}$ values and enzyme concentrations onto Avicel at $10^{\circ} \mathrm{C}$. The result indicates a rapid adsorption of enzyme on Avicel at lower enzyme concentrations, and then remains in equilibrium.

The adsorption isotherm, Equation (1), can be rearranged as follows:

$$
(\mathrm{E}) /(\mathrm{A})=1 /\left\{\mathrm{K}_{\mathrm{ad}}\left(\mathrm{A}_{\max }\right)\right\}+1 /\left(\mathrm{A}_{\max }\right)(\mathrm{E})
$$

The adsorption equilibrium constant $\left(K_{\mathrm{ad}}\right)$ and amount of maximum adsorption $\left(A_{\max }\right)$ were determined from the slope of plots of (E) / (A) vs. (E) using a scattered plot analysis. The adsorption strength of the enzyme is represented by $\mathrm{R}\left(=\mathrm{K}_{\mathrm{ad}} \times\right.$ $A_{\max }$ ) which is the slope of the adsorption isotherm(18) near $\mathrm{P}$ $=0$, As shown in Fig. 6 the plot $(\mathrm{E}) /(\mathrm{A})$ vs (E) gave a fairly straight line which indicates the adsorption of endoglucanase on Avicel follows the langmuir isotherm.

From the results it was found that maximum adsorption of the enzyme was favorable at nearly optimum $\mathrm{pH}$ values of the enzyme, while at higher $\mathrm{pH}$ values adsorption strength of the enzyme decreased (Table 4) which may be due to structural change in substrate binding site of the enzyme at higher $\mathrm{pH}$ values. 


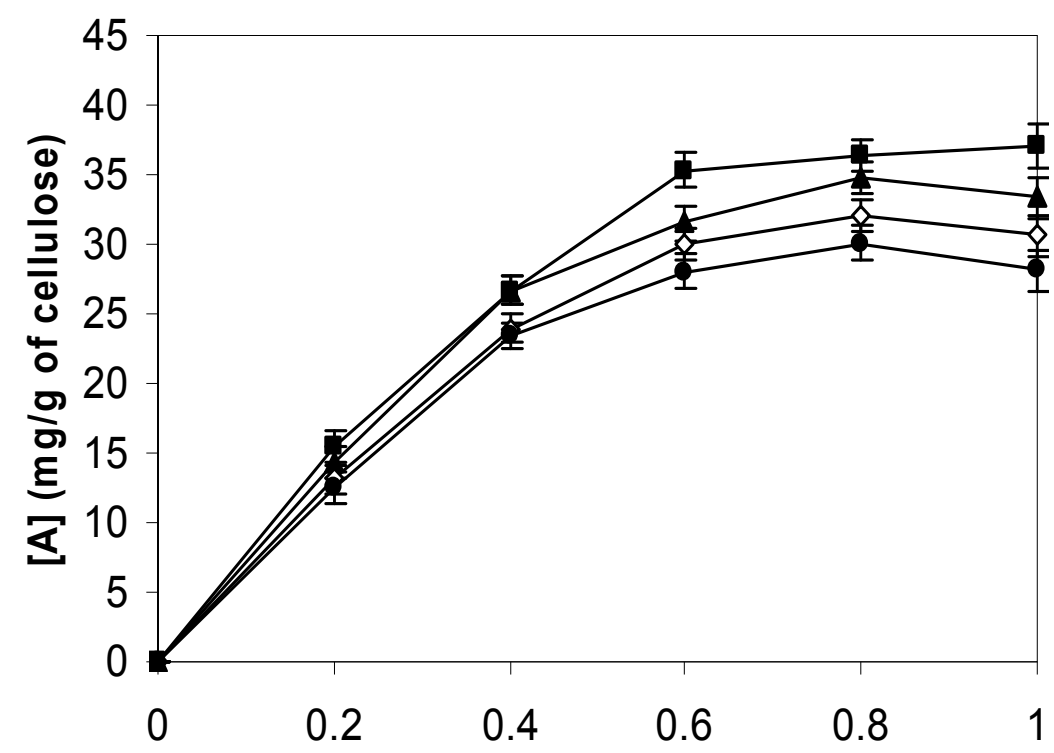

[E] $(\mathrm{mg} / \mathrm{ml})$

$$
\rightarrow-\mathrm{pH} 3 \multimap \mathrm{pH} 5 \multimap \mathrm{pH} 7 \rightarrow \mathrm{pH} 8
$$

Figure 5. Adsorption isotherm of endoglucanase purified from Penicillium notatum NCIM NO- 923 on Avicel at $10^{\circ} \mathrm{C}$. Data presented are average value $+/$ - $\mathrm{SD}$ of $n=3$ experiments.

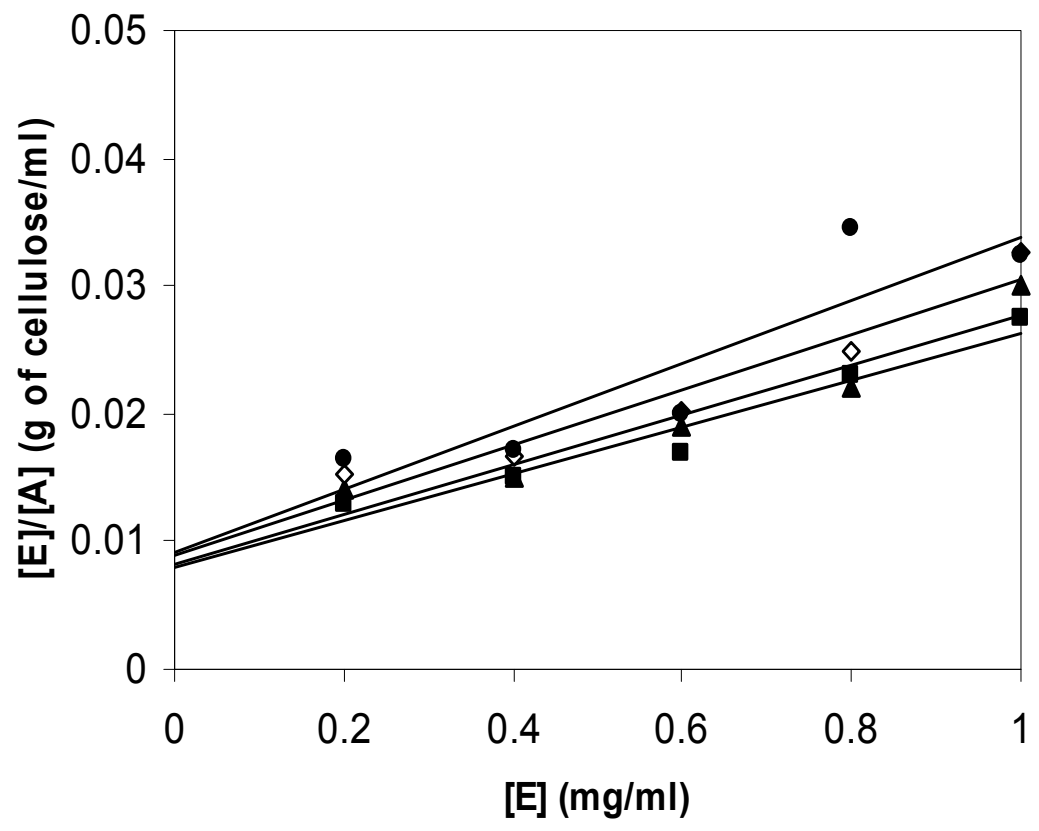

- $\mathrm{pH} 3 \Delta \mathrm{pH} 5 \diamond \mathrm{pH} 7 \bullet \mathrm{pH} 8$

Figure 6. Langmuir-type Adsorption isotherm of endoglucanase purified from Penicillium notatum NCIM NO-923 on Avicel at $10^{\circ} \mathrm{C}$. 
Table 4. Adsorption parameters of purified endoglucanase (CMCase) from Penicillium notatum NCIM NO-923 on Avicel at varying $\mathrm{pH}$ and temperatures.

\begin{tabular}{|c|c|c|c|c|c|c|c|c|c|c|c|c|}
\hline Temperature $\left({ }^{\circ} \mathrm{C}\right)$ & \multicolumn{3}{|c|}{ pH 3} & \multicolumn{3}{|c|}{ pH 5} & \multicolumn{3}{|c|}{ pH 7} & \multicolumn{3}{|c|}{ pH 8} \\
\hline & $\mathbf{A}_{\max }$ & $\mathbf{K}_{\mathrm{ad}}$ & $\mathbf{R}$ & $\mathbf{A}_{\max }$ & $\mathbf{K}_{\mathrm{ad}}$ & $\mathbf{R}$ & $\mathbf{A}_{\max }$ & $\mathbf{K}_{\mathrm{ad}}$ & $\mathbf{R}$ & $\mathbf{A}_{\max }$ & $\mathbf{K}_{\mathrm{ad}}$ & $\mathbf{R}$ \\
\hline 10 & 54.94 & 2.36 & 129.65 & 50.00 & 2.50 & 125 & 47.61 & 2.33 & 110.93 & 40.48 & 2.71 & 109.70 \\
\hline 20 & 53.16 & 2.30 & 122.27 & 50.69 & 2.36 & 119.62 & 46.46 & 2.11 & 98.03 & 40.53 & 2.13 & 86.32 \\
\hline 30 & 50.64 & 2.14 & 108.36 & 49.51 & 2.10 & 103.97 & 45.19 & 2.10 & 94.89 & 39.59 & 1.95 & 77.20 \\
\hline 40 & 49.00 & 1.89 & 92.61 & 48.05 & 1.81 & 86.97 & 43.30 & 1.78 & 77.07 & 39.61 & 1.68 & 66.54 \\
\hline
\end{tabular}

\section{CONCLUSION}

This analytical study revealed that the fungi Penicillium notatum NCIM NO-923 produced significantly high amount of endoglucanase under mixed fermentation using cabbage and bagasse which were too inexpensive and easily available substrates for enzyme production. The $55 \mathrm{kDa}$ enzyme exhibited low activation energy for carboxymethyl cellulose hydrolysis; low $\mathrm{K}_{\mathrm{m}}$ values while high $\mathrm{V}_{\max }$ and $\mathrm{K}_{\text {cat }}$ values, which indicate a high efficiency of the enzyme towards cellulose hydrolysis.

Apart from these, the purified endoglucanase was quite thermostable which is a unique property because elevated temperatures are used in cellulose saccharification process to protect both substrate and products of the enzymatic reaction from microbial contamination and deterioration. Study on the enzyme adsorption at varying $\mathrm{pH}$ and temperature was also important from industrial view point because a large amount of bound enzymes are unutilized due to lack of the knowledge of adsorption kinetics. All these characteristics make the endoglucanase promising for application in industries especially from textile and paper industries. Furthermore this is the first report on purification and thermodynamics study of endoglucanase from Penicillium notatum NCIM NO-923 under solid state fermentation of waste cabbage.

\section{ACKNOWLEDGEMENTS}

Authors are gratefully acknowledged to the University
Grants Commission [Sanction No: F- 3/2007 (BSR)/11114/2008(BSR)] and CSIR New Delhi for financial assistance.

\section{REFERENCES}

1. Beldman, G.; Voragen, A.G.J.; Rombouts, F.M.; Searle, V.; Leeuwen, M.F.; Pilnik, W. (1987). Biotechnol. Bioeng. 30, 251-257.

2. Berlin, A.G.; Gusakov, A.V.; Sinitsyna, O.A.; Sinitsin, A.P. (2000). Appl. Biochem. Biotechnol. 88, 345-352.

3. Eyring, H.; Stearn, A.E. (1939). Chem Rev. 24, 253-270.

4. Gaitán-Hernández, R.; Esqueda, M.; Gutiérrez, A.; Beltrán-García, M. (2011) Braz. J. Microbiol. 42, 30-40.

5. $\quad$ Godfrey, T.; West, S. (1996). $2^{\text {nd }}$ ed. London:Macmillan Press. 360-371.

6. Jain, S.; Parriche, M.; Durand, H.; Tiraby, G. (1990). Enzyme Microb. Technol. 12, 691-695.

7. Kalogeris, E.; Christakopoulos, P.; Katapodis, P.; Alexious, A.; Valchou, S. ( 2003). Proc. Biochem. 38, 1099-1004.

8. Khan, S.M.A.; Reilly, P.J.; Ford, C. (2000). Starch. Starke. 52, 385-397.

9. Lowry, O.H.; Rosebrough, N.J.; Farr, A.L.; Randall, R.J. (1951). J Biol. Chem. 193, 265-267.

10. Marx, J.C.; Collins, T.; D’Amico, S.; Feller, G.; Gerday, C. (2007). Mar. Biotechnol. 9, 293-304.

11. Miller, G.I. (1959). Anal. Chem. 31, 426-428.

12. Petre, M.; Zarnea, G.; Adrian, P.; Gheorghiu, E. (1999). Resour. Conserv. Recycl. 27, 309-332.

13. Rashid, M.H.; Siddiqui, K.S. (1998). Proc. Biochem. 33, 109-115.

14. Segel, I.H. (1975) John Willey \& Sons; 1975.

15. Siddiqui, K.S.; Saqib, A.A.; Rashid, M.H.; Rajoka, M.I. (2002). Enzyme Microb.Technol. 7, 467-474.

16. Teather, R.M.; Wood, P.J. (1982). Appl. Environ. Microbiol. 38, 148158.

17. Vieille, C.; Zeikus, J.G. (1996). Trends Biotechnol. 14, 183-190.

18. Wood, T.M. (1989). Coughlan, M.P. London: Elsevier Applied Science. ISBN 1-85166411-4, 17-35. 